\title{
Sinusitis pada Anak
}

\author{
Rinaldi, Helmi M. Lubis, Ridwan M. Daulay, Gabriel Panggabean
}

\begin{abstract}
Infeksi saluran pernapasan akut (ISPA) merupakan kasus yang sering ditemukan pada anak. Diperkirakan 0,5\%-10\% ISPA mengakibatkan komplikasi sinusitis. Sinusitis adalah infeksi sinus paranasal dengan gejala ISPA yang menetap atau makin berat dalam kurun waktu tertentu. Tiga faktor yang berperan dalam terjadinya sinusitis adalah ostium yang tertutup, penurunan jumlah atau fungsi silia serta berubahnya viskositas sekret. Dengan anamnesis dan pemeriksaan fisik yang teliti dapat ditegakkan diagnosis sinusitis akut pada anak. Pada sinusitis kronis, CT scan merupakan alat bantu diagnosis yang dapat dipercaya. Diagnosis banding antara lain cystic fibrosis dan inverted papilloma. Pada umumnya sinusitis dapat sembuh dengan terapi medikamentosa. Amoksisilin merupakan antibiotik utama disertai dengan pemberian antihistamin, nasal dekongestan dan steroid. Anak yang tidak memberikan respon dengan terapi medikamentosa yang maksimal atau dengan komplikasi dapat dilakukan tindakan pembedahan.
\end{abstract}

Kata kunci: infeksi saluran pernapasan akut, sinusitis

$\mathcal{7}$ nfeksi saluran pernapasan akut atas, sering ditemukan dalam praktek dokter anak. Anak - anak diperkirakan setiap tahunnya ratarata mengalami 6-8 kali infeksi saluran napas akut dibanding dewasa yang hanya 2-3 kali dalam setahun. Diperkirakan 0,5\%-10\% ISPA mengakibatkan komplikasi sinusitis. ${ }^{1,2}$ Lasley memperkirakan sebanyak 6\%-13\% anak sampai usia 3 tahun pernah menderita sinusitis. ${ }^{3}$ Di poliklinik Pulmonologi anak RS Cipto Mangunkusumo Jakarta, dari 823 pasien batuk kronik berulang, 73 pasien menderita sinusitis. ${ }^{1}$

Terdapat hubungan yang erat antara infeksi saluran pernapasan atas dan bawah, khususnya kelainan sinus

\footnotetext{
Alamat korespondensi:

Dr. Rinaldi.

Bagian Ilmu Kesehatan Anak Fakultas Kedokteran Universitas Sumatera Utara/ RSUP H. Adam Malik

Jl. Bunga Lau no.17 Medan.

Telepon. (061) 8361721 - 8365663 Fax. (061) 8361721

E-mail : bikafkusu@telkom.net ; kotak Pos 697 Medan - 20136
}

dan paru. Hidung, nasofaring dan saluran napas bagian bawah merupakan satu kesatuan fungsional yang saling berhubungan secara timbal balik, sehingga setiap gangguan saluran napas bagian atas dapat menyebabkan atau disertai gangguan pada saluran napas bagian bawah atau sebaliknya. ${ }^{1}$ Hubungan antara bronkitis dan sinusitis dikenal sebagai sinobronkitis. ${ }^{4}$

Tujuan penulisan ini adalah untuk mengulas definisi, patofisiologi, patogenesis, diagnosis dan tata laksana sinusitis pada anak.

\section{Definisi}

Sinusitis bakterial akut adalah infeksi sinus paranasal dengan gejala ISPA yang menetap atau makin berat dalam waktu kurang dari 30 hari. Gejala yang menetap berupa sekret hidung (post nasal discharge), batuk siang hari (yang dapat makin berat pada malam hari), atau keduanya dalam waktu lebih dari 10 hari. Gejala yang makin berat ditandai dengan suhu sedikitnya $39^{\circ} \mathrm{C}$ dan 
sekret yang kental (purulent nasal discharge) yang timbul bersamaan selama sedikitnya 3 hari berturutturut. ${ }^{5}$ Sinusitis bakterial sub akut adalah infeksi bakteri pada sinus paranasal yang berlangsung antara 30-90 hari, gejala akan sembuh sempurna ${ }^{5}$ sedangkan sinusitis kronik adalah episode inflamasi sinus paranasal lebih dari 90 hari, pasien akan mengalami gejala gangguan pernapasan yang menetap seperti batuk, rinorhea dan hidung tersumbat. ${ }^{5}$

\section{Patofisiologis dan Patogenesis}

Sinus paranasal terbentuk sebagai evaginasi membran mukosa meatus nasalis. Lapisan mukosa sinus paranasal sama dengan lapisan mukosa hidung. Sinus maksila dan etmoid mulai berkembang selama kehamilan. Sinus frontalis mulai berkembang pada usia 1-2 tahun, bersamaan dengan sinus sfenoid, maka tidak akan terlihat secara radiologis sampai usia 5-6 tahun. ${ }^{6}$

Tiga faktor utama berperan pada fisiologi sinus paranasal adalah ostium yang terbuka, silia yang berfungsi efektif dan pengeluaran sekret yang normal. Retensi sekret dalam sinus paranasal dapat diakibatkan oleh obstruksi ostium, penurunan jumlah atau fungsi silia atau produksi yang berlebihan atau berubahnya viskositas sekret, diikuti dengan infeksi sekunder sehingga terjadi peradangan mukosa sinus paranasal. ${ }^{1,6,7}$ Variasi faktor lokal, regional atau sistemik bisa menimbulkan obstruksi kompleks osteomeatal. ${ }^{8}$ Faktor lokal dan regional meliputi deviasi septum, polip nasal, variasi anatomis seperti atresia koana atau konka bulosa, benda asing, edema yang berhubungan dengan peradangan virus, bakteri, alergi maupun radang selaput hidung non alergi. Faktor sistemik seperti sindrom diskinesia silia, cystic fibrosis dan defisiensi imunologis. ${ }^{8}$

Faktor paling sering yang menyebabkan terjadinya sinusitis adalah ISPA yang disebabkan oleh virus. ${ }^{9}$ Bagaimana infeksi virus dapat menyebabkan sinusitis masih belum jelas, namun diperkirakan respon peradangan terhadap virus menyebabkan tertutupnya sinus, pertukaran oksigen menjadi terganggu, sehingga memicu tumbuhnya bakteri dan timbul infeksi. Gerakan silia pada mukosa sinus menjadi sangat terganggu sehingga timbul penumpukan sekret dan penebalan mukosa sinus.

Organisme yang sering ditemukan pada sinusitis anak, biasanya sama seperti yang ditemukan pada otitis media seperti Streptococcus pneumonae, Staplyllococcus pyogenes, Haemoplylus influenzae dan Moraxella catharalis. ${ }^{10,11}$ Pada kasus kronis, Staplyllococcus pnemonial, Streptococcus haemolyticus dan bakteri anaerob sering ditemukan. ${ }^{6}$

\section{Diagnosis}

Diagnosis sinusitis berdasarkan gambaran klinis, pemeriksaan fisik dan penunjang. ${ }^{1,5}$

Tabel 1 menunjukkan gejala sinusitis pada penelitian Wald dkk (1961), Said ( 1988 ) dan Arruda dkk (1990).

Tabel 1. Gejala klinis sinusitis ${ }^{12-14}$

\begin{tabular}{|c|c|c|c|}
\hline \multirow[b]{2}{*}{ Gejala } & \multicolumn{2}{|c|}{ Penulis (persentase) } & \multirow[b]{2}{*}{$\begin{array}{c}\text { Arruda dkk } \\
\quad(1990)\end{array}$} \\
\hline & $\begin{array}{c}\text { Wald dkk } \\
\text { (1961) }\end{array}$ & $\begin{array}{l}\text { Said } \\
(1988)\end{array}$ & \\
\hline Batuk & 80,0 & 100,0 & 100,0 \\
\hline Pilek & 76,7 & 92,3 & 75,0 \\
\hline Hidung tersumbat & - & 78,8 & 91,7 \\
\hline Nyeri kepala & 33,3 & 30,7 & 33,3 \\
\hline Nyeri sinus & 30,0 & 17,3 & 8,3 \\
\hline Demam & 30,0 & - & 0,0 \\
\hline Nyeri tenggorok & $23,3-$ & - & - \\
\hline Fetor oris & 50,0 & - & - \\
\hline
\end{tabular}

\section{Pemeriksaan Fisis}

Pada sinusitis, pemeriksaan fisik tidak khas. Kadangkala dijumpai adanya sekret nasal, kelainan pada septum, livide pada konka nasal dan post nasal discharge, serta nyeri pada sinus. ${ }^{5,12}$

\section{Pemeriksaan penunjang}

Prosedur penunjang diagnostik untuk sinusitis akut meliputi transiluminasi, ultrasonografi, foto polos sinus paranasalis, ct scan dan magnetic resonance imaging (MRI). ${ }^{15,16}$ Banyak penulis yang menyatakan bahwa transiluminasi tidak dapat digunakan untuk mendiagnosis sinusitis pada anak, demikian juga pemeriksaan ultrasonografi. Ultrasonografi digunakan hanya untuk mengevaluasi sinus maksila dan itupun hanya memiliki hasil minimal dalam menegakkan diagnosis. 


\section{Foto polos sinus paranasalis}

Pemeriksaan foto polos ini merupakan pemeriksaan standar utama untuk sinusitis. Kekurangan foto polos adalah sering ditemukan hasil positif dan negatif palsu. Tiga jenis proyeksi yang digunakan untuk diagnosis sinusitis dengan pemeriksaan foto polos yaitu 1 . Waters position untuk evaluasi sinus maksila dan frontal, 2. Caldwell position untuk evaluasi sinus etmoidalis, dan 3. Proyeksi lateral untuk evaluasi ukuran adenoid, masa di nasofaring dan kelainan di sfenoid. ${ }^{15}$

\section{Computed Tomography Scanning (CT Scan)}

Penggunaan ct scan untuk diagnosis sinusitis pada anak sangat membantu, terutama sinusitis kronis. Hasil yang didapat menggambarkan keadaan sinus dan kompleks osteomeatal. ${ }^{16}$

\section{Magnetic Resonance Imaging (MRI)}

Penggunaan MRI sangat baik untuk mengetahui kelainan soft tissue dari sinus paranasal, namun terbatas dalam pencitraan kelainan tulang, sehingga MRI tidak dapat mengevaluasi sinusitis akut maupun kronis. ${ }^{16}$

\section{Diagnosis banding}

1. Cystic fibrosis, merupakan penyakit yang memiliki karakteristik infeksi bronkopulmoner kronik, sering diikuti obstruksi jalan napas, malabsorpsi dan kegagalan pertumbuhan. Pada anak sering ditemukan ISPA dan polip hidung. Untuk mendiagnosis digunakan pemberian sweat test yang mengandung sodium yang tinggi. ${ }^{17}$

2. Inverted papilloma, merupakan tumor hidung dan sinus tersering. Memiliki karakteristik muncul dari meatus media dan menyebar ke sinus maksila. Sangat jarang mengenai kedua sisi. ${ }^{18}$

\section{Tata laksana sinusitis}

\section{Terapi medikamentosa}

Pada sinusitis akut, diberikan amoksisilin $(40 \mathrm{mg} /$ $\mathrm{kgbb} / \mathrm{hari}$ ) yang merupakan first line drug, namun jika tidak ada perbaikan dalan 48-72 jam, dapat diberikan amoksisilin/klavulanat. Sebaiknya antibiotik diberikan selama 10-14 hari. ${ }^{19}$
Pada kasus sinusitis kronis, antibiotik diberikan selama 4-6 minggu sebelum diputuskan untuk pembedahan. Dosis amoksisilin dapat ditingkatkan sampai $90 \mathrm{mg} / \mathrm{kgbb} / \mathrm{hari} .{ }^{19}$

Pada pasien dengan gejala berat atau dicurigai adanya komplikasi diberikan antibiotik secara intravena. Sefotaksim atau seftriakson dengan klindamisin dapat diberikan pada Streptococcus pneumoniae yang resisten. ${ }^{20}$ (Tabel 2)

Tabel 2. Dosis terapi antibiotik pada sinusitis anak ${ }^{19,20,21,22,23}$

\begin{tabular}{lc}
\hline Antibiotik & Dosis (mg/kgbb/hari) \\
\hline Amoksisilin & 40 \\
Amoksisilin/klavulanat & $40 / 10$ \\
Eritromisin/sulfisoxazol & $50 / 150$ \\
Sulfametoxazol-trimetoprim & $40 / 8$ \\
Sefuroksim & 30 \\
Sefiksim & 8 \\
Klindamisin & 30 \\
Klaritromisin & 15 \\
Azitromisin & 10 \\
\hline
\end{tabular}

\section{Terapi tambahan}

Terapi tambahan meliputi pemberian antihistamin, dekongestan, dan steroid. ${ }^{8,21}$.

Antihistamin: antihistamin merupakan kontra indikasi pada sinusitis, kecuali jelas adanya etiologi alergi. Pemberian antihistamin dapat mengentalkan sekret sehingga menimbulkan penumpukan sekret di sinus, dan memperberat sinusitis. ${ }^{21}$

Dekongestan: dekongestan topikal seperti oksimetazolin, penileprin akan menguntungkan jika diberikan pada awal tata laksana sinusitis. Aktifitasnya akan mengurangi edem atau inflamasi yang mengakibatkan obstruksi ostium, meningkatkan drainase sekret dan memperbaiki ventilasi sinus. Pemberian dekongestan dibatasi sampai 3-5 hari untuk mencegah ketergantungan dan rebound nasal decongestan. Pemberian dekongestan sistemik, seperti penilpropanolamin, pseudoefedrin dapat menormalkan ventilasi sinus dan mengembalikan fungsi pembersih mukosilia. Dekongestan sistemik dapat diberikan sampai 10-14 hari. ${ }^{21}$

Steroid : steroid topikal dianjurkan pada sinusitis kronis. Steroid akan mengurangi edem dan inflamasi 
hidung sehingga dapat memperbaiki drainase sinus. Untuk steroid oral, dianjurkan pemberiannya dalam jangka pendek mengingat efek samping yang mungkin timbul. ${ }^{21}$

\section{Pembedahan}

Untuk pasien yang tidak responsif dengan terapi medikamentosa yang maksimal, tindakan bedah perlu dilakukan. Indikasi bedah apabila ditemukan perluasan infeksi intrakranial seperti meningitis, nekrosis dinding sinus disertai pembentukan fistel, pembentukan mukokel, selulitis orbita dengan abses dan keluarnya sekret terus menerus yang tidak membaik dengan terapi konservatif. ${ }^{24}$ Beberapa tindakan pembedahan pada sinusitis antara lain adenoidektomi, irigasi dan drainase, septoplasti, andral lavage, caldwell luc dan functional endoscopic sinus surgery (FESS). ${ }^{24}$

\section{Daftar Pustaka}

1. Rahajoe N, Supriyatno B, Chatab F. Batuk kronik dan atau berulang pada anak. Tinjauan pengaruh sinusitis. Dalam: Rahajoe N, Rahajoe NN, Boediman I, Said M, Wirjodiarjo M, Supriyatno B, penyunting. Perkembangan dan masalah Pulmonologi anak saat ini. Pendidikan Kedokteran Berkelanjutan (PKB) Ilmu Kesehatan Anak FK UI XXXIII. Jakarta: Balai Penerbit FK UI; 1994. h. 129-41.

2. Nash D, Wald E. Sinusitis. Pediatrics in review, 2001; 22:1-9.

3. Lasley MV, Saphiro GG. Rhinitis and sinusitis in Children. Immunology on allergy clinics of North America 1999; 19:437-49.

4. Chmielik M, Zajac B. Sinobronchial syndrome. New Med. 1999; 12:1-3.

5. Sub Commite on management of sinusitis and Commite on Quality improvement. American Academy of Pediatrics. Clinical practice guideline: Management of sinusitis. Pediatrics 2001; 108:798-806.

6. Neil EH, Peter GS. Sinusitis. Dalam: Behrman RE, Kliegman RM, Arvin AM, penyunting. Nelson textbook of pediatrics. Edisi ke 16. Philadelphia: WB Saunders; 2000. h. 1264.

7. Clement ARP. Management of sinusitis in infants and young children. Dalam:Schaefer DS, penyunting. Rhi- nology and sinus disease. Edisi ke 1. A problem oriented approach. St Louis: Mosby;1998. h. 105-29.

8. Jhosephson G, Roy S. Pediatric rhinosinusitis : Diagnosis and management. Journal of pediatrics 1998: 14;1521.

9. Naclerio RM, Gungor A. Etiologic factors in inflammatory sinus disease.. Dalam: Kennedy DW, Bolger WE, Zinreich SJ, penyunting. Diseases of the sinuses, diagnose and management. London: BC Decker Inc. Hamilton; 2001. h. 47-55.

10. Winther B, Gwaltney JM. Microbiology of sinusitis. . Dalam: Kennedy DW, Bolger WE, Zinreich SJ, penyunting. Diseases of the sinuses, diagnose and management. London: BC Decker Inc.Hamilton; 2001. h. 77-83.

11. Lund VJBacterial sinusitis; etiology and surgical management. Pediatr Infect Dis J 1994; 13:S58-63.

12. Arruda LK, Mimika IM, Sole D. Abnormal maxillary sinus radiograph in children: Do they represent bacterial infection ? Pediatrics 1990; 85: 553-8.

13. Wald ER, Reilly JS, Casselbrant M. Treatment of acute maxillary sinusitis in childhood : A compeative study of amoxicillin and cefaclor. J Pediatr 1994; 104:297-302.

14. Said M. Penatalaksanaan sinobronkitis pada anak. Dalam: Rahajoe NN, Said M, Gazali MV. Naskah lengkap: Beberapa masalah klinis praktis pulmonologi anak. Jakarta: BP FKUI,1988. h. 37-51.

15. Karjomanggolo WT. Aspek pencitraan dalam diagnosis dan tatalaksana penyakit saluran napas pada anak. Dalam: Rahajoe N, Rahajoe NN, Boediman I, Said M, Wirjodiarjo M, Supriyatno B, penyunting. Perkembangan dan masalah Pulmonologi anak saat ini. Pendidikan Kedokteran Berkelanjutan (PKB) Ilmu Kesehatan Anak FK UI XXXIII. Jakarta: Balai Penerbit FK UI; 1994. h. 81-3.

16. Zeifer $\mathrm{AB}$. Imaging of the nose and paranasal sinuses. Dalam:Schaefer DS, penyunting. Rhinology and sinus disease. A problem oriented approach. Edisi ke 1. St Louis: Mosby;1998. h. 3-27.

17. Facer GW, Kern EB. Sinusitis: Current concept and management. Dalam : Bailey BJ. Penyunting. Head and neck surgery otolaryngology. Edisi ke 2. Philadelphia: JB Lippincott;1993. h. 366-70.

18. Giebink GS. Childhood sinusitis; Pathophisiology, diagnosis \& treatment. Pediatr Infect Dis.J 1994; 13;S558.

19. Mackay DN. Antibiotic therapy of the rhinitis \& sinusitis. Dalam : Settipane GA, penyunting. Rhinitis. Edisi ke-2. Rhode Island: Ocean Side Publication; 1991. 
h. 253-5.

20. Ioannidis PAJ, Lau J. Technical report : Evidence for the diagnosis and treatment of acute uncomplicated sinusitis in children; A systematic overview. Pediatrics 2001; 108:1-8.

21. Kennedy DW. Medical management of sinusitis: Educational goals \& management guidelines. Annals of otology rhinology and laryngology, International Conference on Sinus Disease: Terminology, staging, therapy; 1995; Suppl 167: S22-30.

22. O’Brien KL, Dowell SF, Schwartz B, Marcy SM, Philips
WR, Gerber MA. Acute sinusitis- principles of judicious use of antimicrobial agents. Pediatrics, 1998; 101:1747.

23. Ferranti DS, Ioannidis PAJ, Law J, Aninger WV, Barza M. Are amoxycillin and folate inhibitors as effective as other antibiotics for acute sinusitis? A meta analysis. BMJ 1998; 317:632-6.

24. Montgomery W, Singer M, Hamaker R. Terapi bedah pada sinusitis. Dalam: Ballenger JJ, penyunting. Penyakit THT, kepala dan leher. Edisi terjemahan, Jakarta: Binarupa aksara; 1993. h. 255-73. 